\title{
COVID-19 pandemi döneminde Türkiye'de e-ticaret ve e-ihracat
}

\begin{tabular}{lll}
\hline Araştırma Makalesi & DOI: https://doi.org/10.51177/kayusosder.777097 \\
Gönderi Tarihi:05.08.2020 & Kabul Tarihi: 21.11 .2020 & Online Yayın Tarihi: 31.12 .2020 \\
\hline
\end{tabular}

Özet

1990'lardan beri yaşadığımız teknolojik gelişmeler, önemli değişikliklere yol açmıştır. Teknolojik devrim de denilen, yaşanan bu gelişmelerle birlikte e-ticaret", "e-devlet” gibi kavramlar hayatımıza girmiştir. Teknolojik devrimle birlikte üretilen mal ve hizmetler işletmelerin satış ve pazarlama anlayışında değişme yaratırken, tüketicilerin ise istek ve ihtiyaçlarını satın alma alışkanlıklarını ve tercihlerini etkileyen faktörlerde değişim sağlamıştır. Türkiye'de e-ticaret kullanımı son yıllarda yaygınlaşırken, e-ticaret yoluyla alışverişlerin de arttı̆̆ gözlemlenmiştir. Küresel sınır ötesi e-ticaret de ülkeler arasında yaygınlaşmaktadır. Covid-19 Pandemisi de dijital teknolojileri, internet üzerinden alışverişin önemini daha da ortaya koymuştur. İnsanlar artık zamandan da tasarruf etmek amacıyla, sosyal mesafe ve hijyen nedeniyle internetten alışverişe yönelmişlerdir.

Bu çalışmada Türkiye'de e-ticaret ve ihracat verileri incelenmiş, Covid-19 Pandemi döneminde de Türkiye'deki elektronik ticaretin seyri ele alınmıştır. En çok e-ihracatı yapılan ürün kategorisi ise hazır giyim olarak tespit edilmiştir. Seyahat ve turizm, salgın öncesi dönemde e-ticarette en çok tercih edilen ürün kategorisi içindeyken; salgın döneminde ise en çok azalış gösteren sektör olmuştur.

Anahtar Kelimeler: e-ticaret, e-ihracat, Covid-19, Dünya Ticaret Örgütü

\section{E-trade and e-export of Turkey in COVID-19 pandemic period}

\begin{abstract}
The technological developments since the 1990s have caused crucial changes in the world economy. Thanks to this great change "technological revolution", new concepts like "e-commerce" and "e-government were introduced. This technological revolution led to a change in the sales and marketing approach of the enterprises, and in the purchasing habits of the consumers. As e-trade becomes widespread in Turkey in recent years, it was observed that the increase in the rate of online shopping relative to the traditional shopping rises in Turkey. Global cross-border e-trade is also becoming widespread among countries. The Covid-19 Pandemic has further revealed the importance of digital technologies and online shopping. People now prefer online shopping due to social distance, hygienic conditions and time saving.

In this study, e-trade and e-export data in Turkey were examined, and the impact of Covid-19 Pandemic on the electronic trade is analysed. The most e-exported product category is determined as textiles. Although travel and tourism were among the most preferred product categories in e-trade in the pre-epidemic period; it has been the most adversely affected sector during the pandemic period.
\end{abstract}

Keywords: e-trade, e-export, Covid-19, World Trade Organisation

\footnotetext{
${ }^{1}$ Dr.Öğr.Üyesi, İstanbul Yeni Yüzyıl Üniversitesi, İ̈BF, Uluslararası Ticaret ve Lojistik Bölümü, ozlem.yilmaz@yeniyuzyil.edu.tr

${ }^{2}$ İstanbul Yeni Yüzyıl Üniversitesi, İ̈BF, Uluslararası Ticaret ve Lojistik Bölümü, onurbayram.com@gmail.com
} 


\section{Giriş}

Dünyadaki mal ve hizmetlerin, düşüncelerin, kültürlerin, hayat görüşlerinin alışverişi ile doğan bütünleşme süreci ile birlikte "küreselleşme" kavramı hayatımıza girmiştir. Küreselleşmenin getirdiği bütünleşme zorunluluğu; ülkeleri, işletmeleri, toplumları ve bireyleri birbirine bağımlı hale getirmiş ve birlikte hareket etme veya belirli kurallar çerçevesinde bağımsız hareket etme durumunu ortaya çıkmıştır. Doğal kaynakların yeryüzündeki dengesiz dağılımı, ülkeler arası ticareti zorunlu kılmıştır. İnsanlar kendi ülkelerinde karşılayamadığ i ihtiyaçlarını gidermek için başka bir ülkeden doğrudan veya dolaylı olarak ürün ve hizmet satın almaktadırlar. Bilişim teknolojilerindeki ve internet ortamındaki geliş̧meler, ticari zekâ ile birleşince alıcı ve satıcının buluşabileceği bir ă̆ meydana gelmiştir. Günümüzde bu ağa katılan ve adapte olabilen işletmeler başarılı olmuş ve işletmelerini büyütebilmişlerdir. Ticaretin artık internet üzerinden de yapılabiliyor olması, dünyayı daha küresel hale getirmiş, ticaret olanaklarını hızlandırmıştır.

$\mathrm{Bu}$ araştırmada, e-ticaretin ve e-ihracatın önemi ve kapsamı ile birlikte Türkiye'de e-ticaretin ve e-ihracatının gelişimi incelenmiştir. Türkiye'deki internet alışverişinin yıllar itibariyle gelişimi, özellikle hangi alanlarda internet alışverişinin yapıldığ 1 ve e-ticaretin geldiği nokta araştırma konusudur. 2019 yılında Çin'de başlayan ve tüm dünyaya yayılan Covid-19 pandemisi ile birlikte değişen alışveriş alışkanlıkları ve e-ticaretin yükselişi çalışmada dikkate alınmıştır. Öncelikle e-ticaretin kapsamına, türlerine ve e-ihracata değinilmiş, ardından Türkiye'de e-ticaretin gelişimi, kullanımı ve sektör büyüklüğü ile Türkiye'nin e-ihracatı hakkında bilgi verilmiştir. Salgın döneminde internet üzerinden ticareti artan ve azalan sektörler incelenmiştir.

\section{E-ticaret ve e-ihracat kapsamı}

Covid-19 pandemisi ortaya çıktığından bu yana, tüketicilerin evde bulunma sürelerinin artmas ve sınırlı saatlerde alışveriş yapma durumları nedeniyle, e-ticaret hayatımızda önemli yer kapsamaya başlamıştır. E-ihracat kavram olarak e-ticaret içerisinde de kullanılmakta olup, kimi çalışmalarda e-dış ticaret veya sınır ötesi e-ticaret şeklinde de değerlendirilmektedir. Bu bölümde e-ticaret ve ihracat kavramlarına yer verilmiş, iki kavram arasındaki farklardan bahsedilmiş ve istatistiklere yer verilmiştir. Dünya Ticaret Örgütü'nün de e-ticaret ile ilgili yaklaşımı açıklanmış ve konuyla ilgili literatür araştırması yapılmışıtır.

\subsection{Elektronik ticaret (e-ticaret)}

E-ticaret, yeni ve her geçen gün gelişim ve değişim gösteren bir kavram olduğu için bu konuda değişik tanımlar yapılmaktadır:

OECD'ye (Organisation for Economic Co-operation and Development- Ekonomik Kalkınma ve İşbirliği Örgütü) göre bir e-ticaret işlemi, bilgisayar ağları üzerinden özel olarak sipariş almak veya vermek amacıyla tasarlanmış yöntemlerle gerçekleştirilen mal veya hizmetlerin satışı veya alımıdır. Mallar veya hizmetler bu yöntemlerle sipariş edilir, ancak ödeme veya malların veya hizmetlerin nihai teslimatının çevrimiçi olarak yapılması gerekmez (OECD, 2013).

WTO (World Trade Organisation-Dünya Ticaret Örgütü) e-ticaret tanımını ilk kez 1998 yılında E-Ticaret Çalışma Programı'nda ifade etmiştir. WTO'ya göre elektronik ticaret veya e-ticaret "mal ve hizmetlerin elektronik yollarla üretimi, dağıtımı, pazarlanması, satışı veya teslimi" olarak tanımlanmaktadır. Bir e-ticaret işlemi, işletmeler, haneler, bireyler, hükümetler ve diğer kamu veya özel kuruluşlar arasında olabilir (WTO, 1998).

Elektronik Ticaret Rehberi’ne (2006) göre elektronik ticaret, bilgisayar ağları üzerinden, ürünlerin tasarlanması, üretilmesi, reklamının yapılması, ticari işlemler ve tutarların ödenmesi ile ilgili tüm süreci kapsamaktadır (http://www.elektronikticaretrehberi.com/e-ticaret_genel_bilgiler.php). Teknolojinin insanlar arasında hızla yayılması ile hayattaki birçok kavram internet ortamına giriş yapmıştır. İnsanlar bu dijital dünyaya hayatlarını, istek ve ihtiyaçlarını, yeteneklerini ve para kazanma arzusu ile ürettiklerini paylaşmışlardır. Bu paylaşımlar e-ticaret kavramını ortaya çıkarmış ve böylelikle e-ticaret; insanların, firmaların ve kamu kurumlarının sınırsız ihtiyaçları doğrultusunda birçok kavram ile iç içe geçmiştir. Elektronik ticaret; bir ürün veya hizmetin üretiminden pazarlanmasına ve nihai 
satışına kadar tüm faaliyetleri kapsar. Bu faaliyetlerin bir veya birkaçı ya da tamamı elektronik ortamda gerçekleşir.

Elektronik ticaretten önce ticari faaliyetlerin tamamı geleneksel ticaret yöntemleri ile gerçekleştiriliyordu ve bu da zaman kaybına, iletişim problemlerine yol açıyordu. Elektronik ticaretin gündeme gelmesiyle birlikte daha hılı ticaret söz konusu oldu. E-ticaret ile geleneksel ticaret arasında bazı farklar yer almaktadır (Tablo 1). Geleneksel ticarette bilgi edinme yöntemi olarak görüşmeler, dergiler, kataloglar ve reklamlara ihtiyaç duyulurken, e-ticaret yönteminde web sayfalarında bilgiye ulaşmak mümkündür. Geleneksel ticarette, fiyat araştırmasından sevkiyata kadar olan işlemler yazılı olarak gerçekleşirken ve ödeme banka yoluyla yapılırken, e-ticarette ise işlemler internet aracıllı̆̆yla, elektronik postayla gerçekleştirilip, ödeme konusunda ise internet bankacılığı kullanılmaktadır.

Tablo 1. Geleneksel Ticaret ile E-Ticaret Arasindaki Farklar

\begin{tabular}{|l|l|l|}
\hline & Geleneksel Ticaret & E-Ticaret \\
\hline Alışveriş hızı & Zaman kaybı olabilir & Daha hızlıdır \\
\hline Bilgi edinme yöntemi & Dergi, katalog, reklam & Web siteleri \\
\hline Ödeme & Banka yoluyla/Nakit & İnternet bankacııı̆̆ı \\
\hline $\begin{array}{l}\text { İşlemler (fiyat araştırması, } \\
\text { sevkiyat) }\end{array}$ & Yazılı gerçekleşir & İnternet üzerinden gerçekleşir \\
\hline Satış elemanı & Daha çok gerekli olabilir & Daha az satış elemanı gerekli olabilir \\
\hline
\end{tabular}

Kaynak: Bu çalışma esas alınarak yazar tarafından oluşturulmuştur.

Günümüzde elektronik ticaretin yayılmasıyla birlikte ticarete de hareketlilik gelmiştir. Satın almayı yapan firma, tedarik eden firma ve siparişi yapan firma zaman bakımından kazanç sağlamaktadır. Büyük zaman kayıplarına neden olabilen bilgi edinme, talep bildirimi, talep onayı, fiyat araştırması, sipariş verme, stok kontrolü, sevkiyat hazırlığı süreci, irsaliye kesimi, fatura kesimi, teslimat onayı ve ödeme süreçlerinde hız faktörü ön plana çıkmış ve elektronik ticaret sayesinde bu işlemler saniyeler içerisinde gerçekleştirilebilmiştir.

Elektronik ticaret ile birlikte işletmelerin yönetim faaliyetlerinde de birtakım değişiklikler meydana gelmiştir. İşletmelerdeki tüm bilgiler elektronik ortamda yer almaya başlayınca, işletme içindeki veya dışındaki tüm paydaşlar herhangi birisine veya herhangi bir zamana gerek duymadan istediği bilgiyi istediği zamanda elde edebilmiş ve hız faktörü ortaya çıkmıştır. İşletmeler elektronik ticaretin getirdiği hız performansı ile hareketlilik kazanmış ve müşterilerinin değişen istek ve ihtiyaçlarına kısa sürede cevap verebilme yeteneğine kavuşmuştur. Böylece işletmeler var olan veya potansiyel müşterilerini rakip firmalara kaçırmamış olmaktadır. Ayrıca elektronik ortam sayesinde işletme çalışanları, mekan fark etmeksizin elektronik ortam vasıtasıyla çalışma grupları oluşturma olanağına sahip olmuşlardır (Elektronik Ticaret Rehberi, 2006). Elektronik ticaret, işletmeler arasında rekabeti arttırmakta, işletmelerdeki genel maliyet düzeyini düşürmekte, ürün ve hizmete maliyetlerini fiyatlara yansimaktadır.

Tüketici bakış açısından ise internet alışverişi, daha az zaman harcamak, bir satış elemanı baskısından uzak alışveriş işlemini uygun bir atmosferde tamamlamak, bir satın alma ürünü / hizmeti hakkında daha fazla bilgi toplamak ve tercih edilen ürünler için bazen uygun değerleri yakalamak içindir (Demirbaş, 2014, s. 1). Tüketiciler, online platformlar sayesinde ürün satın alabilmenin yanında ürün hakkında ulaşmayı arzu ettikleri bütün bilgilere kolayca ulaşabilmekte ve bununla beraber farklı ürünlerin karşılaştırmasını yapabilmektedirler (Güven, 2020, s. 265).

Kısacası, bu gibi faktörlerle birlikte pazar gücünün tüketiciye geçişi sağlanmaktadır. Ticari faaliyetlerin elektronik ortama kayması ile birlikte meydana gelen aracı sayısındaki azalma veya yok olma ya da siber aracılar gibi yeni fonksiyonlara sahip aracıların tedarik zincirinde yer almaya başlaması gibi durumlar da ortaya çıkmıştır. Aynı zamanda işletmelerin 7 gün 24 saat çalışabilme yeteneğine sahip olmasını sağlamıştır. İşletmelerin alım - satım faaliyetlerinde etkileşimli elektronik pazarlama imkanı ile etkin ve hızlı müşteri talep yönetimi, müşteriler için elektronik ödeme imkanı, etkileşimli tedarik 
zinciri yönetimi, etkileşimli stok yönetimi, bankacılık ve sigortacılık hizmetlerinde etkinlik ve hız, sanal anket yapma ve kamuoyu görüsslerini alabilme, doğrudan müşteriye hitap edilebilen birebir pazarlama anlayışı ortaya çıkmıştır (Yeşil, 2010, ss. 95-99).

Elektronik ticaret sadece bir ürün veya hizmetin satışını kapsamamaktadır. Bir ürün veya hizmetin üretiminden satış sonrası hizmetine kadar tüm aşamalarını kapsamaktadır. Ancak her ürün ve hizmetin elektronik ortamda gerçekleşmesi günümüz şartları için mümkün değildir. Üretilen farklı ürünler veya farklı hizmetler aynı dijital ortamdan sipariş edilse dahi müşterilere teslim şekli değişiklik gösterebilir. Örneğin; bir online alışveriş sitesinden sipariş edilen montun teslimi elektronik ortamdan yapılamaz. Bu durumda ürünün teslimi için geleneksel ticaret yöntemlerine başvurulur (Yeşil, 2010, s. 36). Bunun yanı sira müzik dinleme, gazete, kitap ve dergi okumak gibi hizmetler elektronik ortamda gerçekleşir.

Elektronik ticaret, katılımcılarına göre 5 şekilde gerçekleşebilir (Alan, 2017; Ersoy, 2015):

- $\quad$ Işletmeden işletmeye elektronik ticaret (B2B - business to business)

Şirket içi veya şirketler arası yapılan ticarettir. İşletmeler üretim yapabilmek için ihtiyaç duydukları hammadde ya da ara malı başka bir işletmeden sağlayabilirler ve bunu elektronik ticaret vasıtasıyla gerçekleştirebilirler. Bu tip işletmeler kendi aralarında kurdukları bayilerle sadece işletmeler arası alım satım yaparlar. Alibaba.com dünyanın en büyük B2B elektronik ticaret platformu olup, aynı zamanda işletmeden tüketiciye de ulaşan bir platformdur. 1999 yılında Çin'de kurulmuştur.

\section{- $\quad$ Işletmeden tüketiciye e-ticaret (B2C - business to consumer)}

İşletmeler ürettikleri mal ya da hizmeti nihai kullanıcıya yani tüketiciye satıyorsa bu tür işletmeden tüketiciye elektronik ticarettir. Hedef kitle bireysel tüketicilerdir. Burada tüketiciler, işletmelerin online alışveriş sitelerinden veya uygulamalarını kullanarak alışveriş yaparlar. Hepsiburada.com, biletix.com, yemeksepeti.com, Amazon.com B2C e-ticaret platformlarına örnektir.

\section{- $\quad$ Tüketiciden tüketiciye e-ticaret (C2C-consumer to consumer)}

Tüketiciler daha önce satın aldıkları ürünleri online alışveriş sitelerine, sahibi oldukları internet sitelerine veya başka herhangi bir dijital platforma koyarak başka tüketicilere satışa sunabilirler. Dünyada bu yöntemle alışveriş yapılan en popüler elektronik ticaret sitesi "Ebay"dır. Gittigidiyor, sahibinden.com gibi büyük e-ticaret sitelerinde ve 2.el satan sitelerde bu alışveriş türü mümkündür.

\section{- $\quad$ Issletmeden kamu idaresine e-ticaret (B2G-business to goverment)}

İşletmeler ile kamu idareleri arasındaki ticari işlemler, vergiler, gümrük işlemleri, sosyal güvenlik, istatistiki bilgi paylaşımı, kamu ihalelerine ilişkin duyurular vs. işletmeden kamu idaresine elektronik ticaret faaliyetlerine örnek olarak gösterilebilir.

\section{- $\quad$ Tüketiciden kamu idaresine e-ticaret (C2G-consumer to goverment)}

Halk ile devlet arasındaki vergi ödemeleri, sigorta işlemleri, hukuki işlemler elektronik ortamlarda gerçekleştirilebilir. Tüketici ile kamu idaresi arasında her türlü vergi, sağlık ve hukuksal etkinliği kapsamaktadır. Henüz yaygın örnekleri olmasa da bu kategoride ehliyet, pasaport başvuruları, sosyal güvenlik primleri vergi ödemeleri, vb. uygulamalar ile Elektronik Devlete geçişin sağlanması planlanmaktadır.

E-ticaretin tüm ticaret içindeki payı da gün geçtikçe artmaktadır. Online perakendenin toplam perakendeye bölünmesiyle çevrimiçi perakendenin payı Deloitte Danışmanlık firması tarafından hesaplanmıştır (Tablo 2). Tabloda 2015 ve 2018 yılında yapılan pazar büyüklüğü raporlarına ait veriler yer almaktadır. Gelişmiş ülkeler arasında $\mathrm{ABD}$ ve İngiltere e-ticaret alanında en yüksek paya sahiptir. Online perakendenin toplam perakendeye oran1 2015 y1lında \%12,6 iken, 2018 y1lında \%17'ye çıkmıştır. Gelişmekte olan ülkeler arasında ise Çin e-ticaret alanında önemli yol almış ve payını $\% 23,7$ 'ye çıkararak, internet alışverişinde en yüksek paya sahip olan ülkedir. Türkiye'de son y1llarda gelişen e-ticaret 2015 yılında \%2 iken, 2018'de \%5'e çıkmıştır. 
Tablo 2. Ülkeler itibariyle Çevrimiçi Perakendenin Toplam Perakendenin İçindeki Payı

\begin{tabular}{|c|c|c|c|}
\hline & Ülke & $\begin{array}{l}\text { Online perakende / Toplam } \\
\text { perakende }(\%, 2015)\end{array}$ & $\begin{array}{l}\text { Online perakende / Toplam } \\
\text { perakende }(\%, 2018)\end{array}$ \\
\hline \multirow{6}{*}{ 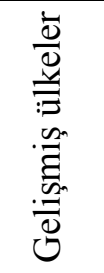 } & İngiltere & 12,6 & 17,0 \\
\hline & ABD & 9,2 & 13,7 \\
\hline & Almanya & 7,9 & 11,0 \\
\hline & Fransa & 6,8 & 8,8 \\
\hline & Japonya & 7,2 & 8,6 \\
\hline & İspanya & 3,3 & 4,6 \\
\hline \multirow{6}{*}{ 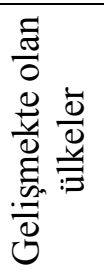 } & Çin & 9,7 & 23,7 \\
\hline & Polonya & 6,8 & 6,7 \\
\hline & Brezilya & 4,1 & 7,2 \\
\hline & Rusya & 3,8 & 5,0 \\
\hline & Hindistan & 1,9 & 5,2 \\
\hline & Türkiye & 2,0 & 5,3 \\
\hline
\end{tabular}

Kaynak: Türkiye Bilişim Sanayiciler Derneği (2019). Türkiye'de e-ticaret 2018 pazar büyüklügü. TÜBİSAD, http://www.tubisad.org.tr/tr/images/pdf/tubisad_e-ticaret_2019_pazar_buyuklugu_raporu.pdf

\subsection{E-ihracat (sinır ötesi e-ticaret)}

E-ihracat, elektronik ortamda yani internet üzerinden ihracatın yapılmasıdır. Sınır-ötesi eticarette alıcı ve satıcı aynı ülkede ikamet etmemekte, genellikle aynı para birimini kullanmamakta, farklı dil konuşmakta ve farklı yargı hükümlerine tabi olmaktadırlar (T.C. Ticaret Bakanlığı, 2019). Eihracatın önemli bir avantajı, mesafeden kaynaklanan dezavantajları azaltması, hatta kimi durumlarda yok etmesidir (UIB, 2017, s.22). İnternet üzerinden sipariş ile tüketiciler kapıdan teslimat gibi kolaylıklar da beklemektedir. Tüketiciler açısından sınır ötesi alışverişin en önemli nedenleri arasında fiyatların daha uygun olması, yerli sayfalarda mevcut olmayan ürünlerin ve daha fazla seçeneğin bulunmasıdır (İhracatı Geliştirme Merkezi, 2018). Ancak sınır ötesi e-ticarette uluslararası şirketlerin, ticaret yaptıkları ülkelerdeki tüketicilerin beklentilerini, özelliklerini, tercihlerini dikkate alarak ürün arzını farklılaştırabilirler. $\mathrm{Bu}$ açıdan global ve lokal kelimelerinin baş harflerinden oluşan "glokalleşme"yi yani yerelleşmeyi strateji olarak benimseyerek tüketici odaklı faaliyette bulunmaları önemlidir.

E-ihracat ve e-ticaret farkları Tablo 3'te gösterilmektedir.

Tablo 3. Yurtiçi e-ticaret ve e-ihracat arasindaki farklar

\begin{tabular}{|l|l|l|}
\hline \multicolumn{1}{|c|}{ Yurt içi e-ticaret } & \multicolumn{1}{c|}{ E-İhracat } \\
\hline Hedef kitle & Bireysel tüketiciler & Kurumsal ve uluslararası firmalar \\
\hline Ticaret kapsam1 & İnternet alışverişi & İthalat ve ihracat \\
\hline Ticaret kurallar1 & Ulusal e-ticaret kuralları & Uluslararası ticaret kuralları \\
\hline İnternet sitesi & $\begin{array}{l}\text { Türkçe internet sitesi kurulumu } \\
\text { Türkçe arama motoru optimizasyonu } \\
\text { Kişisel verilere ilişkin mevzuat }\end{array}$ & $\begin{array}{l}\text { Yabanc1 dilde internet sitesi } \\
\text { Yabancı dil arama motoru optimizasyonu } \\
\text { Kişisel veri ve kurumsal bilgilerle ilgili } \\
\text { yabancı ülkelerdeki mevzuat }\end{array}$ \\
\hline Ödeme & $\begin{array}{l}\text { Yerli kredi kartı } \\
\text { Ödeme işlemcileri } \\
\text { Vergiler (KDV, ÖTV) }\end{array}$ & $\begin{array}{l}\text { Yabancı kredi kartı } \\
\text { Uluslararası ödeme işlemcileri } \\
\text { Yabancı ülkelerdeki vergiler }\end{array}$ \\
\hline Lojistik & Yerli kargo ve posta servisleri & $\begin{array}{l}\text { Çok uluslu kargo, ülke içi kargo } \\
\text { Gümrük işlemleri }\end{array}$ \\
\hline Satış sonras1 & $\begin{array}{l}\text { Müşteri hizmetleri } \\
\text { İade }\end{array}$ & $\begin{array}{l}\text { Yabanc1 dilde müşteri hizmetleri } \\
\text { Yurt dişı iade }\end{array}$ \\
\hline
\end{tabular}

Kaynak: Türkiye Ekonomi Politikaları Araştırma Vakfı (2014). Türkiye'de e-ihracat: fırsatlar ve sorunlar. TEPAV Yayınları., s. 25; Kara, M. (2019). E-dış ticaret ve ihracatta müşteri bulma yöntemleri. İstanbul Üniversitesi, s. 8. 
E-ihracatta e-ticaretten farklı olarak müşteri kitlesi değişiktir. E-ticarette bireysel tüketiciler hedef kitle olurken, e-diş ticarette kurumsal ve uluslararası firmalar hedef kitledir. E-ticaretin kapsamı internet üzerinden alışveriş iken, e-dış ticaretin kapsamı ihracat ve ithalattır. E-ticarette ulusal e-ticaret kuralları geçerken, e-dış ticarette uluslararası kurallar ve dış ticaret prosedürleri geçerlidir. E-ticarette Türkçe internet sitesi kurulumu gerekliyken, e-ihracatta yabancı dilde internet kurulumu yapılmaktadır. Ödeme açısından da farklılıklar vardır. E-ticarette yurt içi ödeme söz konusu olduğu için yerli kredi kartları yeterlidir, ayrıca ödemeler yurt içindeki vergilendirmeye tabiidir. Ancak e-ihracatta, ödemeler yabancı ülkedeki vergilere tabii, gümrük işlemleri söz konusu ve yabancı kredi kartlarıyla mümkün olmaktadır.

$\mathrm{B} 2 \mathrm{~B}$ ve $\mathrm{B} 2 \mathrm{C}$ modelleri e-ihracatta kullanılmaktadır. Eğer müşteri bir firma ise, B2B; eğer müşteri nihai tüketiciyse B2C kavramı kullanılmaktadır. Dünyada da e-ihracat giderek artan bir eğilim izlemektedir. 2014 yılında 1,3 trilyon dolar değerinde sınır ötesi e-ticaret yapılırken, bu rakam 2018 y1lında 2 kattan fazla artarak 2,8 trilyon dolara yükselmiştir (Şekil 1).

Şekil 1. Küresel Sinır Ötesi E-Ticaret

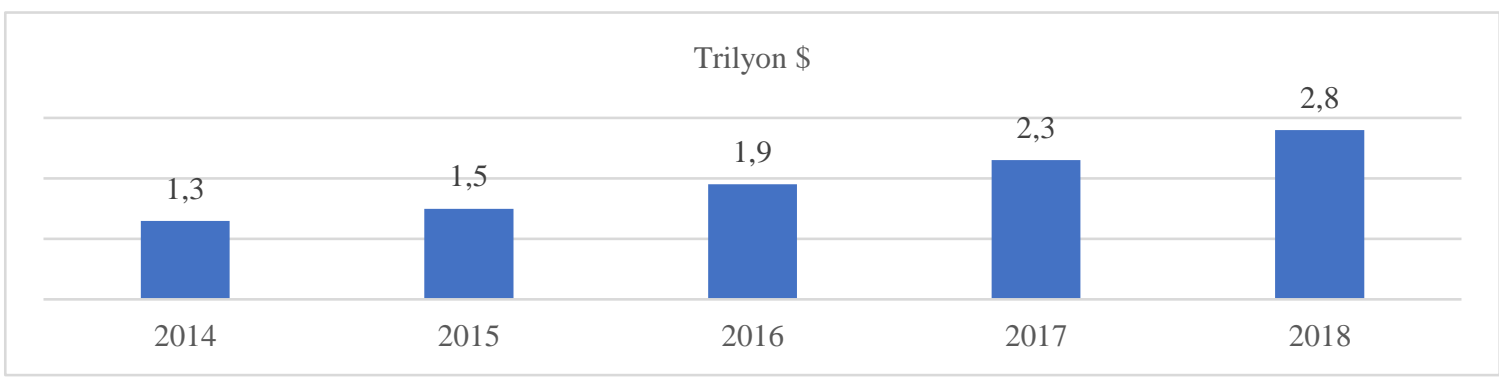

Kaynak: Webrazzi (2018). E-ihracat rehberi. https://webrazzi.com/2018/11/14/turkiyenin-e-ihracat-gelecegi-vehedef-pazarin-belirlenmesindeki-anahtar-unsurlar/

2018 yılı verilerine göre küresel e-ticarette, tüketicilerin internet üzerinden alışverişini en çok tercih ettiği ürün kategorisi olarak \%30 pay ile hazır giyim gelmektedir (Şekil 2). Ardından en çok satılan ürünler elektronik, sağlık-güzellik, kitap-müzik, mücevher ve saat gelmektedir.

Şekil 2. Sinır Ötesi E-Ticarette En Çok Satın Alınan Ürün Kategorileri

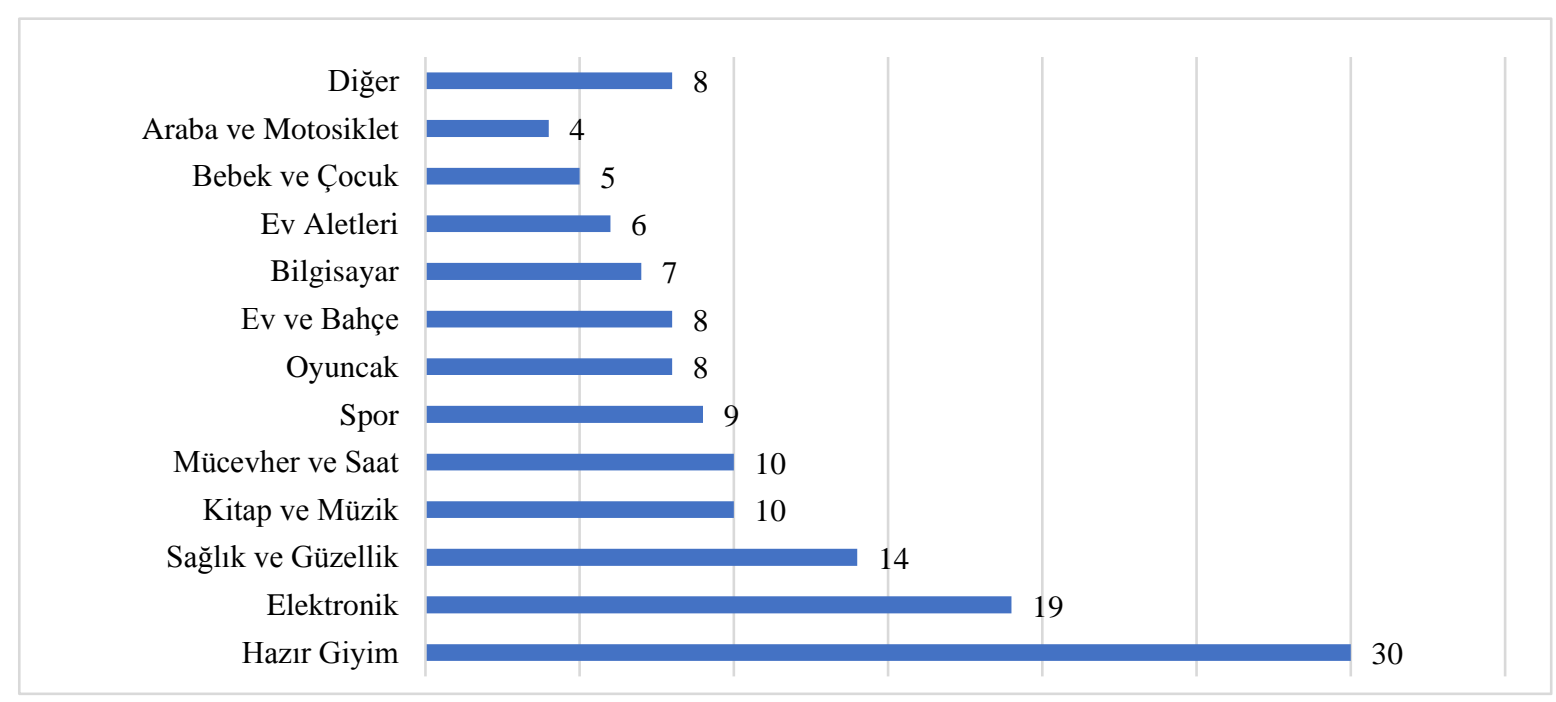

Kaynak: Webrazzi (2018). E-ihracat rehberi. https://webrazzi.com/2018/11/14/turkiyenin-e-ihracat-gelecegi-vehedef-pazarin-belirlenmesindeki-anahtar-unsurlar/ 
Küreselleşen ticaret ile, artık sınır ötesi alışverişler mümkün hale gelmiş, firmalar kendi ülke sınırlarının ötesine geçerek pazar ağlarını genişletip, ünlerini yayabiliyorken, tüketiciler de uygun koşullarda ve istedikleri ürünleri internet üzerinden sinır ötesi firmalardan tedarik edebilmektedir. Böylelikle, tüketiciler fiyat karşılaştırması da yaparak internet üzerinde istedikleri ürünlere ulaşabilmektedir. Dolayısıyla, küresel sınır ötesi e-ticaret yıllar bazında artmaktadır.

Şirketlerin sınır ötesi e-ticarete adaptasyonu açısından dikkate almaları gerektiren birtakım unsurlar vardır. Öncelikle, e-ihracatta yabancı dilde hizmet verebilecek internet siteleri ve çağrı merkezleri, sınır ötesi tüketicilere ulaşmak açısından önemlidir. Kargo ve ödeme kolaylıklarının sağlanması, iade koşulları, tüketiciye hizmeti sağlayabilecek yeterli depo ve sevkiyat sistemlerinin olması gibi önemli unsurlar da e-ihracatın gelişmesi açısından gereklidir. Ayrıca sınır ötesi alışverişlerde, tüketicilerin alışveriş yaptıkları şirketin internet sitesindeki bilgilerine, markasına güven duyması sağlanmalıdır. Bu açıdan kredi kartlarıyla ödemede müşteriye güven hissinin verilmesi, kalite belgelerinin sağlanması şirketler açısından önem arz etmektedir.

\subsection{Dünya Ticaret Örgütü’nün e-ticaret yaklaşımı}

Elektronik ticarete ilişkin pazara giriş konusu Dünya Ticaret Örgütü (DTÖ) bünyesinde ilk kez 1998 yılı içerisinde tartışılmaya başlandı. 1998 Cenevre'deki Bakanlar Konferanslarında Elektronik Ticaret Çalışma Programı değerlendirildi ve Doha 2001; Hong Kong 2005; 2009'da Cenevre; Cenevre 2011; Bali 2013; Nairobi 2015; ve Buenos Aires 2017 Konferanslarında, elektronik ticaret ile ilgili Konsey oluşturuldu. Genel Konsey e-ticaretle ilgili çalışmalara devam etmektedir. Konferanslarda ayrıca, elektronik işlemlere gümrük vergisinin uygulanmamasına bir sonraki oturumlarına kadar devam etme konusunda anlaştılar. Aralık 2019'daki Genel Konsey'de Üyeler, Çalışma Programına ve gümrük vergisi konusunda aldıkları kararlara 12. Bakanlar Konferansına kadar devam etme kararı aldı (WTO, 2019, s.1).

DTÖ’de e-ticaret üzerine çalışmalar, E-Ticaret Üzerine Çok Taraflı Bir Çalışma Programı kapsamında hala devam etmektedir. 2017'deki On birinci Bakanlar Konferansi'ndan bu yana, bir grup üye, Ortak Açıklama Girişimi kapsamında e-ticaretle ilgili olası kuralları tartışmaktadır.

Covid-19 salgını süresince elde edilen deneyimlerden yola çıkarak DTÖ'deki e-ticaret tartışmaları - hem Çalışma Programı hem de Ortak Açıklama Girişimi müzakereleri bakımından devam etmektedir (WTO, 2020, s.6). Şimdiye kadarki süreçte e-ticaret işlemlerinde gümrük vergisinin alınmaması kararına varılmıştı. Bundan sonra da Covid-19 pandemi süresince, e-ticarette ortaya çıkan zorluklar ve faydalar bu alanda küresel iş birliği için bir teşvik olabilir ve sınır ötesi e-ticarete düzenlemeler getirilebilir.

\subsection{Literatür taraması}

E-ticaret, özellikle e-ihracatla ilgili akademik yayınlar sınırlıdır. Çalışmalarda e-ihracat kavramı e-ticaret içerisinde, sınır ötesi e-ticaret ya da e-dış ticaret kapsamında değerlendirilmiştir. Bu çalışmayı ilgilendiren e-ticaret ve ihracatla ilgili akademik yayınlar tarih sırasına göre aşağıda verilmiştir.

Altıntaş vd. (2006) e-ticaret engelleriyle ilgili araştırmalarında, Türkiye'de ihracatçı KOBI'ler üzerinde araştırma yapmıştır. KOBİlerin E-ticaret kullanımı teknolojiye uyum sağlamadan ve süre özelliğinden etkilenmektedir. Çalışanların eğitimi ve teknik becerisi e-ticaret kullanımında etkili olmaktadır.

Terzi (2011), e-ticaretin uluslararası ticaret ve istihdam üzerindeki etkisini araştırmış; internetin, diğer ticaret engellerini kaldırdığını, uluslararası ticareti de teşvik edip, uluslararası ticaret hacmini arttıracağını vurgulamıştır. Ayrıca elektronik ticaret sayesinde bilgi ve iletişim teknolojileri sektöründe doğrudan ve dolaylı olarak yeni işler yaratılacakken, diğer yandan e-ticaretin iş kayıplarına neden olacağını belirtmiştir.

Kara ve Coşkun (2012) e-dış ticarette karşılaşılan sorunları gıda sektörü açısından incelemiş̧ir. E-ticarette karşılaşılan güven sorunu, dil bilme sorunu için çözümler öne sürülmüş, üniversitelerde eticaret derslerinin olması gerektiği önerilmiş, web sitelerinin sağlıklı kullanılması tavsiye edilmiştir.

Kuşat (2016) işletmeden işletmeye (business to busines-B2B) elektronik pazaryerlerinin dış ticaret açısından başarı ve güvenilirlik kriterlerini incelemiştir. Çalışmaya göre, bir firma, çevrimiçi 
pazarlamaya katılmadan önce geleneksel iş koşullarını bu yeni koşullarla uyumlu hale getirecek organizasyonel düzenlemeleri yapmalıdır. Aksi takdirde, özellikle B2B çevrimiçi pazar yerleri uluslararası ticarette başarıya ve popülerliğe ulaşmayacaktır.

Xing (2017), çalışmasında, gelişmekte olan ve en az gelişmiş 21 ülke ve 30 OECD ülkesi paneli kullanarak internet ve e-ticaretin benimsenmesinin ikili ticaret akışları üzerindeki etkisini incelemiştir. Çalışma, yüksek hızlı internet ve güvenli sunucular ile donatılmış Bilgi ve İletişim Teknolojisinin verimli kullanımının, gelişmekte olan ve en az gelişmiş bölgeler için e-ticaret potansiyellerinin kilidini açmak için önemli bir kilometre taşı olduğunu belirtmektedir.

Tu ve Shangguan (2018), uluslararası ticaretin yeni bir itici gücü olan sınır ötesi e-ticareti Çin'i bir vaka çalışması olarak kullanarak araştırmışlardır. Dört faktörün gelecekteki firsatlar için önemli olduğu sonucuna varmışlar: hükümetlerin etkisi, gelişmekte olan ülkelerde orta sınıfın yükselişi, teknolojik gelişmeler ve e-ticareti benimseyen daha fazla KOBİ. Öte yandan yazarlara göre kültürel farklılıklar, müşteri güveni, lojistik, ödeme ile yasal ve düzenleyici engeller, e-ticaretin karşılaştığı en büyük zorluklar arasındadır.

Mzwri ve Altınkaya (2019), elektronik ticaretin uluslararası ticaret üzerindeki etkisini Türkiye açısından araştırdıkları çalışmalarında, bir ülkenin internet erişimindeki bir artışın, diğer ülkelerle hizmet ticaretinde artış sağlayacağını ve uluslararası ticaretin hacminin e-ticaret yoluyla artacağı sonucuna varmışlardır. Türkiye'de elektronik ticaretin hızlı büyümesi, Türkiye'nin uluslararası ticareti üzerinde etkili olduğunu belirtmişlerdir.

Güven (2020) Covid-19'un, e-ticaret üzerindeki etkisini incelemiştir. Çalışmaya göre, salgın döneminde tüketiciler özellikle sağlık, kişisel bakım ve temizlik ürünlerinde yönelmiştir. Giyim ve aksesuar ürünleri ile lüks tüketim ürünlerinin talebinde ise bir azalma söz konusu olmuştur.

\section{COVID-19 pandemi öncesi Türkiye'nin e-ticareti ve e-ihracatı}

Türkiye'de 90'lı yıllardan itibaren internet kullanılmaya başlanmış ve ilk olarak çoğunlukla kamu tarafından kullanılmıştır. İlerleyen yıllarda dünyadaki gelişmelere paralel olarak Türkiye'de de internet kullanımı özel sektöre ve halkın kullanımına açılmıştır. Özel sektörün girişimleri ile birlikte ticaretin elektronik ortama kaymaya başlaması üzerine, 1997 yılında Bilim ve Teknoloji Yüksek Kurulu (BTYK), elektronik ticaret ağı oluşturulması için bir toplantı gerçekleştirdi ve bu toplantı ile birlikte, elektronik ticaretin önü açılmış oldu. Toplantının ardından Dış Ticaret Müsteşarlı̆̆ı'na "koordinatörlük", TÜBİTAK’a (Türkiye Bilimsel ve Teknik Araştırma Kurumu) ise "sekreterya" görevi verilmiştir. 1998 yılında Dış Ticaret Müsteşarlığ 1 başkanlığında Elektronik Ticaret Koordinasyon Kurulu (ETTK) kurulmuştur. Kurul, Türkiye'de elektronik ticaretin gelişimi için farklı alanlarda çalışmalar yapmıştır. Bilim ve Teknoloji Yüksek Kurulu, Türkiye'de elektronik ticaretin geliştirilmesi ile ilgili, teknik ve idari alt yapı ile yasal ve hukuki düzenlemelerin yapılması ve bunun yanı sıra, ulusal politika ve uygulamaların uluslararası politika ve uygulamalarla uyumlu hale getirilmesi vs. görevleri Elektronik Ticaret ve Koordinasyon Kurulu için belirlemiştir (Demirdöğmez vd., 2018, s. 15).

Türkiye' de elektronik ticaret alanında alınan en önemli kararlardan biri, 5070 sayılı 2004 yılında çıkarılmış olan Elektronik İmza Kanunu'dur. Kanunda Elektronik İmza, başka bir elektronik veriye eklenen veya elektronik veriyle mantıksal bağlantısı bulunan ve kimlik doğrulama amaciyla kullanılan elektronik veri olarak tanımlanmıştır (Elektronik İmza Kanunu, 2004). Elektronik imzanın yasal bir zemin kazanarak ticaret hayatına girmesi ile özel sektörün, kamu idarelerinin ve halkın güvenilir ve hızlı bir şekilde işlemleri gerçekleştirebilmesi sağlanmış oldu.

Türkiye İstatistik Kurumu'nun (TÜIK'in) 2018 yılı "Hanehalkı Bilişim Teknolojileri Kullanım Araştırması'na göre; Şekil 3'te de görüleceği üzere, Türkiye'de internet kullanım oranında son 10 yılda istikrarlı bir artış olduğu görülmektedir. 2008 yılında yüzde 35,9 olan internet kullanım oranı 2018'de yüzde 72,9'a ulaşmıştır. 
Şekil 3. Türkiye'de Yıllara Göre İnternet Kullanım Oranları.

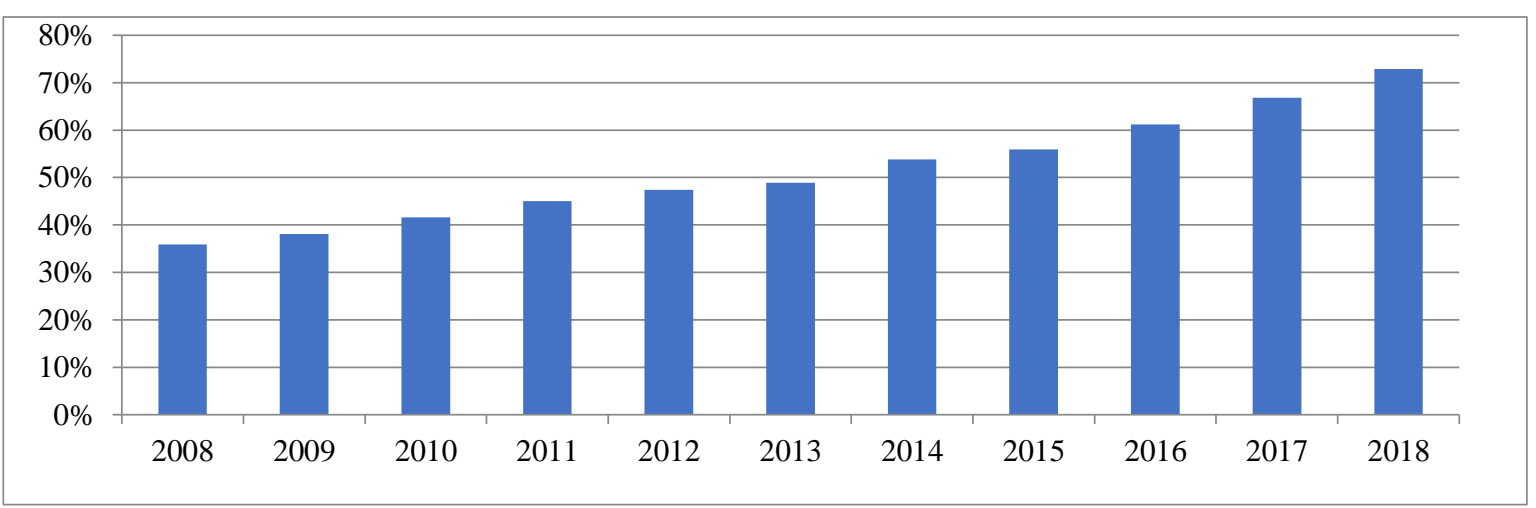

Kaynak: Türkiye İstatistik Kurumu (2019). Hanehalkı bilişim teknolojileri kullanım araştırması (2019). TÜİK. https://data.tuik.gov.tr/Bulten/Index?p=Hanehalki-Bilisim-Teknolojileri-(BT)-Kullanim-Arastirmasi-201930574

TÜİK'in 2018 yılı "Hanehalkı Bilişim Teknolojileri Kullanım Araştırması”nda Türkiye'deki internet kullanıcılarının, interneti hangi amaçlarla kullandığına dair verilere bakıldığında, Türkiye'de yaşayan insanların internet kullanımında yüzde 84,1 'lik oranı ile en büyük payı alan amaç; sosyal medya üzerinden profil oluşturma, mesaj gönderme veya fotoğraf vb. içerik paylaşma olduğu görülmektedir. Bu amac1, yüzde 78,1 ile paylaşım sitelerinden video izleme (Örnek: Youtube), yüzde 69,5 ile internet üzerinden telefon ile görüşme / video görüşmesi (webcam ile), yüzde 68,8 ile sağlikla ilgili bilgi arama (yaralanma, hastalık, beslenme vb.), yüzde 67,8 ile mal ve hizmetler hakkında bilgi arama, yüzde 61,4 ile müzik dinlemek (web radyosu dahil), yüzde 44,8 ile E-Posta gönderme/alma, yüzde 40,0 ile İnternet üzerinden TV izleme (canlı veya kaçırılan programlar dahil), yüzde 39,5 ile internet bankacıllı̆ı, yüzde 35,3 ile oyun oynama ya da indirme, yüzde 34,7 ile web sitesi üzerinden bir doktordan randevu alma (sağl1k kuruluşu ve hastane vb.), yüzde 21,3 ile mal veya hizmet satış1, yüzde 4,4 ile ücretli video izleme takip etmektedir.

Tablo 4. Türkiye'deki Internet Kullanıcılarının Interneti Kullanım Amaçları

\begin{tabular}{|l|c|c|c|}
\hline Amaçlar & Kadın (\%) & Erkek (\%) & Toplam (\%) \\
\hline E-posta gönderme / alma & 37,1 & 51,1 & 44,8 \\
\hline $\begin{array}{l}\text { İnternet üzerinden telefon ile görüşme / video } \\
\text { görüşmesi (webcam ile) }\end{array}$ & 71,3 & 68 & 69,5 \\
\hline $\begin{array}{l}\text { Sosyal medya üzerinden profil oluşturma, mesaj } \\
\text { gönderme veya fotoğraf vb. içerik paylaşma }\end{array}$ & 80,7 & 86,9 & 84,1 \\
\hline Mal ve hizmetler hakkında bilgi arama & 63,3 & 71,5 & 67,8 \\
\hline Müzik dinlemek (web radyosu dahil) & 60,5 & 62,2 & 61,4 \\
\hline $\begin{array}{l}\text { İnternet üzerinden TV izleme (canlı veya kaçırılan } \\
\text { programlar dahil) }\end{array}$ & 39,1 & 40,8 & 40 \\
\hline Ücretli video izleme & 3,6 & 5,1 & 4,4 \\
\hline Paylaşım sitelerinden video izleme (Örnek: Youtube) & 75,9 & 80 & 78,1 \\
\hline Oyun oynama ya da indirme & 29,3 & 40,3 & 35,3 \\
\hline $\begin{array}{l}\text { Sağlıkla ilgili bilgi arama (yaralanma, hastalık, } \\
\text { beslenme vb.) }\end{array}$ & 73,5 & 65 & 68,8 \\
\hline $\begin{array}{l}\text { Web sitesi üzerinden bir doktordan randevu alma } \\
\text { (sağlık kuruluşu veya hastane vb.) }\end{array}$ & 34,8 & 34,7 & 34,7 \\
\hline Mal veya hizmet satış1 & 17 & 24,9 & 21,3 \\
\hline İnternet bankacılığ1 & 27 & 49,8 & 39,5 \\
\hline
\end{tabular}

Kaynak: Türkiye İstatistik Kurumu (2019).

Tablo 4'te görüleceği üzere, TÜIKK tarafından internet kullanım amaçları araştırması yapılırken cinsiyet faktörü de incelenmiştir. Kadınların ve erkeklerin en çok internet kullanım amacı olan "sosyal medya üzerinden profil oluşturma, mesaj gönderme veya fotoğraf vb. içerik paylaşma" amacı kadınlarda 
yüzde 80,7; erkeklerde ise yüzde 86,9 ile ilk sırada yer almaktadır. İşletmeler, elektronik ticarette etkin bir pazarlama faaliyeti gerçekleştirmek için bu veriyi dikkate alıp, dijital dünyadaki pazarlama stratejisine yön verebilirler.

\subsection{Türkiye'de e-ticaret}

Türkiye'de e-ticaret internet kullanımıyla birlikte artış eğilimi göstermektedir. Uluslararası sosyal medya ajansları "We Are Social" ve "HootSuite"in, istatistik ajans1 "Statista" ile ortak olarak hazırladıkları "Dijital Türkiye 2019 E-Ticaret Raporu"na göre, 2017'de 31,7 milyon olan internetten alışveriş yapanların sayısı 2018'de 7,6 milyon kişi artarak 39,3 milyona yükselmişstir (Girişim Haber, 2019).

Dijital Türkiye 2019 E-Ticaret Raporu'na göre, 2018 yılında 39,3 milyon kişi 11 milyar 480 milyon dolar değerinde internet üzerinden alışveriş yapmıştır. Şekil 4'te görüleceği üzere, Türkiye'de 2018 y1lında elektronik ortamda en çok harcama 5 milyar 198 milyon dolar ile seyahate/tatile yapılmıştır. Tatil ve seyahatten sonra en çok satın alınan mallar elektrikli ev aletleri, cep telefonları ve giyim olmuştur. En az harcama yapılan alan ise dijital müzik olarak gerçekleşmiştir.

Şekil 4. Elektronik Ortamdan Alınan Mal ve Hizmet Türü Değerleri, 2018, 1000 \$

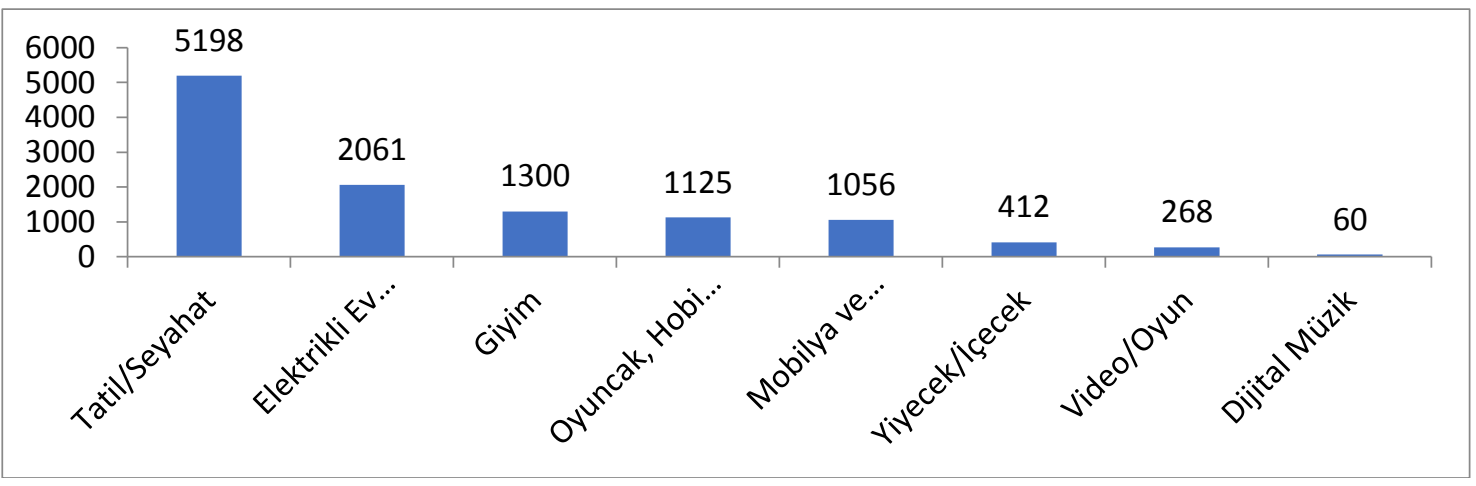

Kaynak: Cin, E. (2019). 2018'de online alışveriş ile tam 60 milyar lira harcadık!

https://www.girisimhaber.com/post/2019/02/25/2018-Yilinda-Internette-60-Milyar-Lira-Harc adik.aspx

Tablo 5'te de yer aldığı üzere hem kadınların hem de erkeklerin internetten en çok satın aldığ mal veya hizmet türünün "giyim, spor malzemeleri” olduğu görülmektedir.

TÜIK'in "Son 12 ay içerisinde kişisel kullanım amacıyla bireylerin internet üzerinden satın aldığı mal ve hizmet türleri" araştırmasına göre, Türkiye'deki bireylerin elektronik ortamdan en çok satın aldıkları mal ve hizmetler "Giyim / spor malzemeleri, seyahat ile ilgili faaliyetler (seyahat bileti, araç kiralama vb.), ev eşyası (mobilya, oyuncak, beyaz eșya vb.)" olarak kadın tüketiciler ve erkek tüketiciler bazında sıralanmaktadır. Cinsiyete göre bakıldığında, kadınlar da erkekler de internet üzerinden en çok giyim ve spor malzemeleri satın almaktadır. Elektronik aletler ev bilgisayar donanımlarını erkekler kadınlara kıyasla internet üzerinden daha çok satın almaktadırlar. İnternet üzerinden en az tercih edilen ürünler ise, kadınlar açısından oyun yazılımı, erkekler açısından ise ilaçtır.

Kadınların internetten giyim, spor malzemeleri alışverişindeki yüzde 77,3'lük oranı, erkeklerin internetten giyim, spor malzemeleri alışverişindeki yüzde 55,9'luk oranına göre oldukça yüksektir. Tablo 5'te bir diğer dikkat çeken veri ise, erkeklerin internet ortamından elektronik araç (cep telefonu, kamera, radyo, TV, DVD, oynatıcı vb.) alışverişinin kadınlara oranla oldukça yüksek olmasıdır. Erkeklerin internet ortamından elektronik araç satın alma oranı yüzde 26,6 iken, kadınların internet ortamından elektronik araç satın alma oranı yüzde 8,2'dir. Reklam veren işletmelerin, hedef kitlelerine daha kolay ulaşabilmeleri için bu verileri dikkate almaları gerekir. 
Tablo 5. Bireylerin Internet Üzerinden Satın Aldı̆̆l Mal ve Hizmet Türü Oranları, 2018

\begin{tabular}{|l|c|c|c|}
\hline $\begin{array}{l}\text { İnternet üzerinden alışveriş yapan bireylerin sipariş } \\
\text { verdikleri ya da satın aldıları mal ve hizmet türleri }\end{array}$ & $\begin{array}{c}\text { Kadın } \\
(\%)\end{array}$ & $\begin{array}{c}\text { Erkek } \\
(\%)\end{array}$ & $\begin{array}{c}\text { Toplam } \\
(\%)\end{array}$ \\
\hline Gıda maddeleri ile günlük gereksinimler & 23,7 & 20,8 & 22,1 \\
\hline Ev eşyası (Mobilya, oyuncak, beyaz eşya vb.) & 24,3 & 28,7 & 26,8 \\
\hline İlaç & 4,1 & 4,6 & 4,4 \\
\hline Giyim, spor malzemeleri & 77,3 & 55,9 & 65,2 \\
\hline Bilgisayar ve diğer ek donanım & 5,4 & 17,6 & 12,3 \\
\hline $\begin{array}{l}\text { Elektronik araçlar (cep telefonu, kamera, radyo, TV, DVD, } \\
\text { oynatıcı vb.) }\end{array}$ & 8,2 & 26,6 & 18,6 \\
\hline $\begin{array}{l}\text { Telekomünikasyon hizmetleri (TV, geniş bant abonelik } \\
\text { özellikleri (ADSL vb.) }\end{array}$ & 11,2 & 19,0 & 15,6 \\
\hline Tatil konaklaması (Otel vb. rezervasyon) & 12,6 & 17,6 & 15,4 \\
\hline Diğer seyahat faaliyetleri (bileti, araç kiralama vb.) & 25,4 & 36,9 & 31,9 \\
\hline $\begin{array}{l}\text { Sportif ve kültürel faaliyetler için bilet satın alımı (sinema, } \\
\text { tiyatro, maç vb.) }\end{array}$ & 15,1 & 18,0 & 16,8 \\
\hline Film, müzik & 6,5 & 8,7 & 7,7 \\
\hline Kitap, dergi, gazete (e-kitap dahil) & 22,3 & 19,3 & 20,6 \\
\hline E-öğrenme araçları (çevrimiçi eğitim siteleri, CD) & 4,8 & 5,0 & 4,9 \\
\hline Oyun ve bilgisayar yazılımı ve güncellemeleri & 2,8 & 9,1 & 6,4 \\
\hline
\end{tabular}

Kaynak: Türkiye İstatistik Kurumu (2019).

Türkiye'de elektronik ticaret sektörünün son 6 yılda istikrarlı bir şekilde büyüdüğü görülmektedir (Şekil 5). 2013 yılında 14 milyar lira olan elektronik ticaret pazarı büyüklüğü, yüzde 35 büyüme kaydederek 18,9 milyar liraya, 2015 yılında yüzde 31 büyüme kaydederek 24,7 milyar liraya, 2016 yılında yüzde 25 büyüme gerçekleştirerek 30,8 milyar liraya, 2017 yılında 42,2 milyar liraya ve 2018 yılında 60,8 milyar liraya yükselmiştir. Bu verilere göre, elektronik ticaret sektörünün son 6 yıldaki ortalama büyüme hızı yüzde 34,4 olarak gerçekleşmiştir.

Şekil 5. Türkiye'de E-Ticaret Sektörünün Ylllara Göre Büyüklüğü

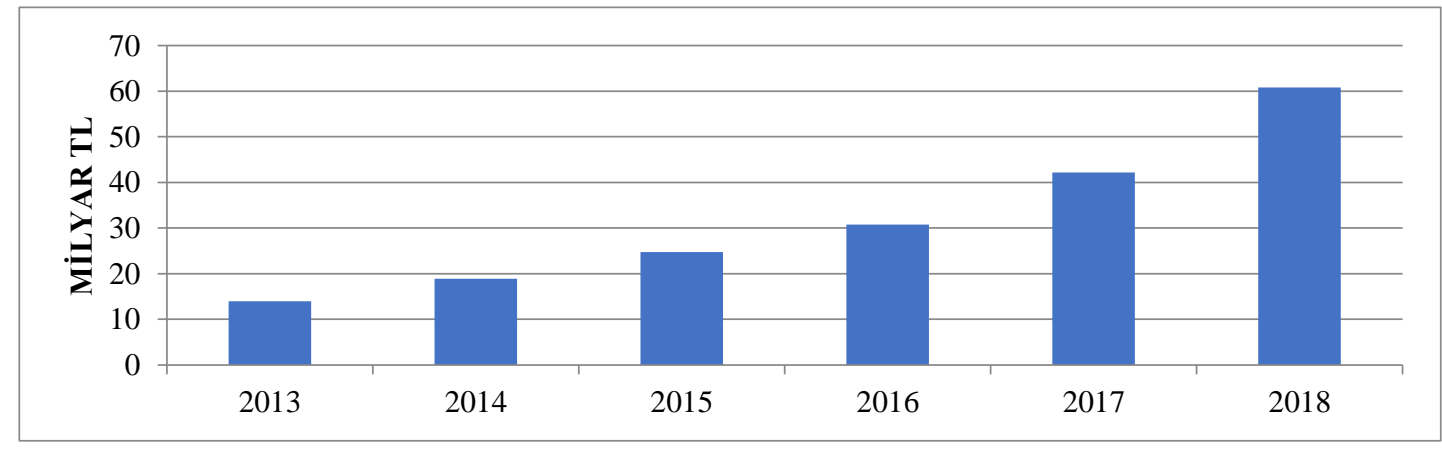

Kaynak: Cin, E. (2019).

Artan nüfus ile birlikte, yoğun çalışma saatleri bireyleri elektronik alışverişe yönlendirmekte, gelecekte de bu sektörün giderek büyümesi beklenmektedir. Ancak şirketlerin geleneksel ticarete alışkın olmaları, e-ticaret konusunda yeterli teknolojik altyapılarının olmaması, tüketicilerdeki güven eksikliği ve dolandırıcılık tehdidi nedeniyle kredi kartıyla alışveriş riski, lojistik sürecinde oluşabilen sorunlar (ürün tesliminde yaşanabilen sorunlar, ürün iadeleri, ilave kargo ücretleri..) Türkiye'de e-ticaretin gelişmesi açısından engel teşkil etmektedir (UTIKAD, 2019, s.10). Kayıt dışı ve dolandırıcılık olaylarını engellemek amacıyla T.C. Ticaret Bakanlığı "Elektronik Ticarette Güven Damgası" uygulamasını başlatmıştır. Şirketlerin e-ticaret içinde yer almasını sağlayabilecek destek programlarının oluşturulması, e-ticaret eğitim programlarının geliştirilmesi ve uzman kişilerin yetiştirilmesi e-ticaretin gelişmesi açısından çok önemlidir (UTIKAD, 2019, s. 11). 
2019 yılı toplam e-ticaret harcamalarının \%85'i yurtiçi harcamalardan oluşurken; \%09'u yurtdışı kaynaklı ödemelerden, \%6'sı da yurtdışına yapılan ödemelerden oluşmaktadır (E-Ticaret Bilgi Platformu, 2020). Ülkemizde toplam 68.457 işletme e-ticaret faaliyeti yürütmektedir (E-Ticaret Bilgi Platformu, 2020).

\subsection{Türkiye'nin e-ihracatı}

Türkiye'de yapılan araştırmalara göre, e-ihracatçılar geleneksel ihracata göre ortalama 11 kat daha fazla pazara ulaşmaktadır (E-Ticaret Günlüğü, 2015).

2018 yılında Türkiye'nin e-ihracat geliri 5.955 milyon ABD doları olarak gerçekleşmiştir (UTIKAD, 2019, s. 8). Türkiye'nin e-ihracatında ABD, Avustralya, Kanada ve Çin en önemli ülkeler arasındadır (UIB, 2017, s. 23). E-ihracatta en çok kullanılan site eBay; en çok e-ihracatı yapılan ürünler ise aşağıdaki gibidir (UİB, 2017, s. 24):

- Giyim, ayakkab1, aksesuar

- Mücevher, saat

- Otomobil parçaları

- Antikalar

- Mobilya, dekorasyon

- Hobi ve zanaat ürünleri

- Bilgisayar, Tüketici elektroniği

- Müzik aletleri

- Güzellik ve bakım ürünleri

Türkiye'de Ekonomi Bakanlığg firmalara e-ihracat desteği verebilmektedir. Bu destekten faydalanmak için Ekonomi Bakanlığına veya İhracatçı Birliklerine başvurmak gerekmektedir. Ancak destek alacak firmalar satacakları ürünleri Türkiye'de üretmeleri gerekmektedir. Şahıs firmaları da kurumsal firmalar da aşağıda belirtilen desteklerden faydalanabilmektedir (E-Ticaret Günlügüu, 2015):

- Yurtdışı pazarına yönelik yabancı web sitelerine verilen reklam giderleri,

-Arama motorlarında yapılan, Türkçe dışında Türkiye’yi hedef almayan reklam harcamaları,

- Yurtdışındaki dergi, gazete, bilboard, televizyon, radyo vb. yerlerde sunulan Türkçe olmayan reklamlar,

-Yurtdışına tanıtım amacıylagönderilen promosyon malzemeleri (kalem, takvim, ajanda vb.),

-Yurtdışında ofis, mağaza, depo ya da showroom açılması halinde ilgili birimlerin kira giderleri,

- Yurtdışında yapılan marka tescil giderleri,

-İhracat amaçlı ve yurtdışında müşteri bulmaya yönelik seyahat giderleri.

Destek oranları ise aşağıdaki gibi belirlenmiş olup, günümüzde de devam etmektedir (ETicaret Günlüğ̈̈, 2015):

- Kira harcamaları için teşvik oranı \%50 ile \%70 arasında değişen oranlarda, yıllık 100 - 120 bin dolara kadar,

- Reklam ve tanıtım faaliyetleri için, \%60 ile 70 arasında değişen oranlarda, yıllık 100 - 250 bin dolara kadar, 
- Marka tescil giderleri için, \%50 ile \%60 arasında değişen oranlarda, yıllık 50 bin dolara kadar, devlet tarafından teşvik sağlanmaktadır.

Ayrıca E-ticaret sitelerine üyelik desteği için 2016 yılına kadar bireysel başvuru kabul edilirken artık bunun yerine toplu başvuru yapılması benimsenmiştir. T.C. Ticaret Bakanlığı İhracat Genel Müdürlüğ̈̈ Pazar Araştırması ve Pazara Giriş Desteği Hakkında Tebliğ (2011/1)'e göre onay verilen internet siteleri Tablo 6'da yer almaktadır.

Tablo 6. E-Ihracat Onayı Verilen Internet Siteleri

\begin{tabular}{|l|l|l|l|}
\hline E-Ticaret Sitesi & Hedef Sektör & Merkez & Aç1lış \\
\hline bysharing.com & Genel & Türkiye & 2013 \\
\hline chemorbis.com & Kimya & Türkiye & 2000 \\
\hline dhgate.com & Genel & Çin & 2004 \\
\hline fibre2fashion.com & Tekstil & Hindistan & 2000 \\
\hline fordaq.com & Orman Ürünleri & Belçika & 2000 \\
\hline globalpiyasa.com & Genel & Türkiye & 2012 \\
\hline kompass.com & Genel & Fransa & 1997 \\
\hline makinecim.com & Makine & Türkiye & 2006 \\
\hline PttTrade.com & Genel & Türkiye & 2016 \\
\hline steelorbis.com & Çelik & Türkiye & 2002 \\
\hline stonecontact.com & Doğal Taş & Çin & 2003 \\
\hline tradeatlas.com & Genel & Türkiye & 2009 \\
\hline tradekey.com & Genel & S.Arabistan & 2006 \\
\hline turkishbusinessplatform.com & Genel & Türkiye & 2012 \\
\hline turkishexporter.net & Genel & Türkiye & 2005 \\
\hline wlw.de & Genel & Almanya & 1995 \\
\hline zoodel.com & Genel/İran & İsviçre & 2009 \\
\hline
\end{tabular}

Kaynak: T.C. Ticaret Bakanlığı İhracat Genel Müdürlüğü (2018). E-ihracat onayı verilen internet siteler. https://ticaret.gov.tr/data/5b8d9c6913b876125c08b4de/TicaretBakanligi_OnayVerilenETicaretSiteleriListesi201 9.pdf

Şekil 2'de belirtildiği üzere, dünyada en çok e-ihracatı yapılan ürün kategorisi hazır giyimdir. Türkiye'nin 2018 yılı ihracat rakamlarına göre hazır giyim \%16 pay ile motorlu kara taşıtları ihracatından sonra ikinci sırada yer almaktadır (TÜİK, 2019b).

Ancak e-ihracat açısından bazı sorunlar işletmelerin küresel e-ticarete entegrasyonu açısından engel teşkil etmektedir (UTIKAD, 2019, ss. 22-25): Bunlardan en önemlisi e-ihracat yapan şirketlerin birçok yabancı dilde hizmet verecek çağnı merkezlerinin ve web sitelerinin olmaması; ödeme açısından ise e-ihracatta genel olarak kullanılan Paypal'ın Türkiye piyasasından çıkması; gümrüklerde daimi personel eksikliği gibi sorunlar dikkate alınmalıdır.

Yurt dışına ihraç edilebilecek yöresel ürünlerde desteklerin arttırılması e-ihracatı teşvik için önemli bir adımdır. Şirketlere yönelik e-ihracat danışmanlık hizmetlerinin arttırılması önemlidir. Eİhracatta güven arttırıcı tedbirlere yönelik planlanacak uygulamalara; uluslararası gözetim ve denetim firmaları tarafından geliştirilecek ürün özelliklerine yönelik kalite belgeleri örnek olabilecektir (UTIKAD, 2019, s. 15).

2018-2020 dönemini kapsayan E-İhracat Stratejisi ve Eylem Planı 06.02.2018 tarihli 30324 sayılı Resmi Gazete' de yayınlanmış ve Eylem Planı'na göre 7 ana hedef belirlenmiştir (06.02.2018 tarihli Resmi Gazete: 47):

- Lojistik kapasitesinin geliştirilmesi (hızlı teslimat yapılması, iade sorunlarının halledilmesi

- Gümrük işlemlerinin hızlı ve masrafsız şekilde sonuçlandırılması (iade edilen ürünlerin üzerindeki idari yüklerin kaldırılması, KDV iadeleri sürecinin iyileştirilmesi) 
- Ürün denetimi ve güvenliğin etkinleştirilmesi (hizmet sağlayıcılar tarafından uyulması gereken güvenlik ve hizmet kalitesi standartlarını, güven damgası verilmesi gibi süreçleri kapsamaktadır)

- Uluslararası rekabetçiliğin geliştirilmesi (işletmelerin teknolojik düzeylerinin arttırılması)

- E-ihracatçı firma sayısının arttırılması (e-ihracat yapmamış KOBİ'lerin e-ihracat firsatları konusunda bilgilendirilmesi)

- E-ihracat potansiyeli olan mikro girişimcilerin e-ihracata yönlendirilmesi

- E-ihracatın geliştirilmesine yönelik uluslararası iş birliklerinin yapılması

Eylem Planı'nda yer alan bu maddelerin gerçekleştirilmesi için adımlar atılması, şirketlerin ihracat olanakları gelişmesini sağlayıp, yeni pazarlara açılmak, sınır ötesi müşteriler sağlamak şirketlerin rekabetçiliğini de arttırıp, Türkiye'nin ihracatına da katkıda bulunacaktır.

\section{COVID-19 pandemi sürecinde e-ticaretin artan önemi}

2019 yılında Çin'de başlayan ve oradan dünyaya yayılan Covid-19 Pandemisi nedeniyle vakalar hızla çoğalmış, bulaşma riski her geçen gün yükselmiş ve bu nedenle insanların evinde geçirdiği süre de artmıştır. Pandemi nedeniyle vaka sayısındaki artışla birlikte, her sektör farklı etkilenmiştir. Alınan tedbirlerle birlikte; kafe, restoran ve alışveriş merkezlerinin geçici süreyle kapanması (sonra belli şartlar altında açılması); marketlerin, işyerlerinin ve bankaların çalışma saatlerinin değişmesi sonucu üretim ve tüketim alışkanlıkları değişmiştir. Tüketiciler bulaşma riskini en aza indirmek ve sosyal mesafeyi korumak amacıyla, fiziksel alışverişten çevrimiçi alışverişe yöneldi. Mağazalar, marketler de e-ticaret yöntemiyle tüketicilere ürün sunmaya devam etmektedirler. Aslında pandemi gösterdi ki, e-ticaret tüketiciler açısından önemli bir çözüm yöntemiydi.

Salgın döneminde internet üzerinden alışverişin en çok market ürünlerinde arttığı (\%186) görülmektedir (Şekil 6). Yaşamak için gerekli olan market ürünleri ve sağl1k ürünleri e-ticarette en çok artış gösteren ürün grupları olmuştur. Ardından kozmetik, kitap/kırtasiye, kuruyemiş salgın döneminde tüketicilerin en çok internet üzerinden alışveriş yapmayı tercih ettikleri ürün gruplarıdır.

Pandemi başlangıcında, "Evde Kal" çağrıları ve seyahat sınırları dolayısıyla, e-ticaret açısından en olumsuz etkilenen ürün guruplarının başında otel (-\%84), uçak bileti (-\%82) ve araç kiralama (-\%79) gelmiştir. Online satışlarda mobilya ürün grubunda $\% 55$; tekstilde de $\% 43$ düşüş yaşamıştır.

Şekil 6. Covid-19 Salgını Döneminde Türkiye'de Ürün Gruplarının Online Satışındaki Değişimler

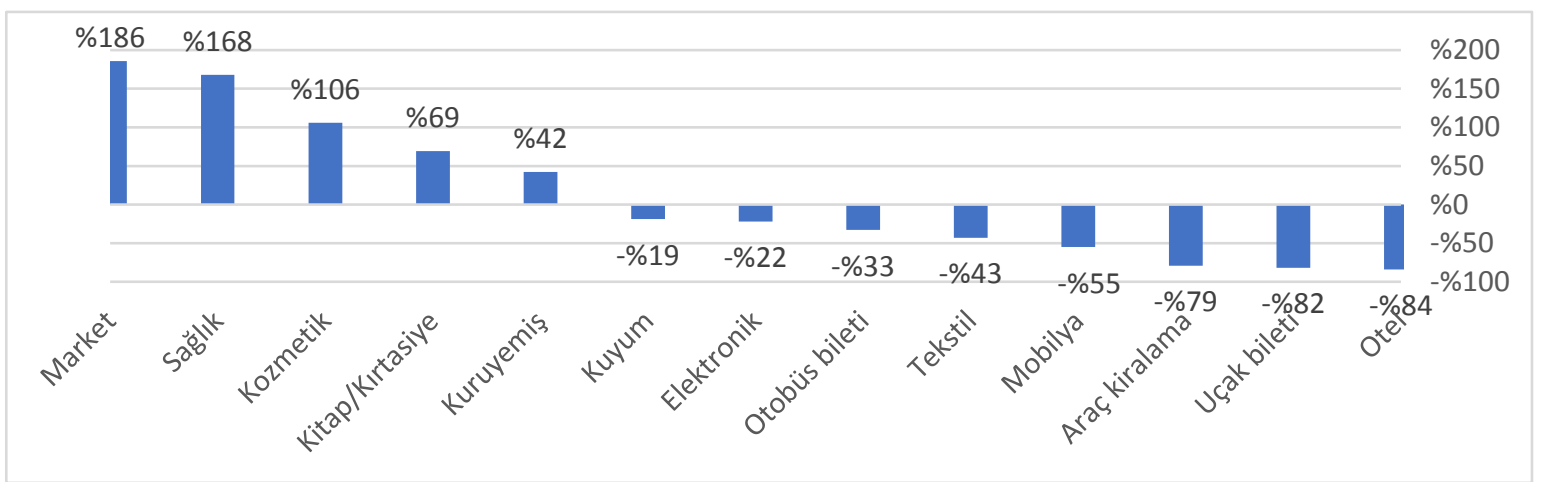

Kaynak: Muradoğlu (2020). Covid-19'la birlikte Türkiye'de online harcama tutarında nasıl bir değişim yaşandı? https://webrazzi.com/2020/04/07/covid-19-la-birlikte-turkiye-de-online-harcama-tutarinda-nasil-bir-degisimyasandi/

Tablo 7 e-ticarette 2019 ve 2020 yıllarının ilk 6 ay kıyaslamasını göstermektedir. 2019 yılının ilk ayındaki e-ticaret verilerine göre 2020 yılının ilk ayında en çok artış gösteren gıda ürünleridir. Bir önceki seneye göre \%434 artış yaşanmıştır. Ardından yazılım ve ev/bahçe ürünler gelmektedir. 
Tablo 7. 2019/2020 ilk 6 aya göre e-ticarette en çok artış gösteren sektörler

\begin{tabular}{|l|l|}
\hline En çok artış gösteren sektör & Artı̧ oran1 \\
\hline G1da süpermarket & $\% 434$ \\
\hline Yazılım & $\% 116$ \\
\hline Ev bahçe & $\% 95$ \\
\hline Beyaz eşya & $\% 90$ \\
\hline Elektronik & $\% 58$ \\
\hline Giyim & $\% 45$ \\
\hline
\end{tabular}

Kaynak: E-Ticaret Bilgi Platformu (2020). E-Ticaret İstatistikleri. https://www.eticaret.gov.tr/istatistikler

2019 yılının ilk ayındaki e-ticaret verilerine göre 2020 yılının ilk ayında en çok azalış gösteren sektör ise seyahattir. Ardından havayolları ve konaklama gelmektedir (Tablo 8).

Tablo 8. 2019/2020 ilk 6 aya göre e-ticarette en çok azalış gösteren sektörler

\begin{tabular}{|l|l|}
\hline En çok azalış gösteren sektör & Azalış oran1 \\
\hline Seyahat & $\% 51$ \\
\hline Havayolları & $\% 42$ \\
\hline Konaklama & $\% 42$ \\
\hline Eğlence sanat & $\% 24$ \\
\hline Araç kiralama & $\% 10$ \\
\hline
\end{tabular}

Kaynak: E-Ticaret Bilgi Platformu (2020).

Covid-19 tüketim alışkanlıklarını e-ticaret lehine değiştirmiş ve internet üzerinden alışverişi arttırmıştır. Bu artışın nedenleri aşağıdaki gibi açıklanmaktadır (E-Ticaret Bilgi Bankası, 2020):

\section{E-Ticaret'in;}

- Pratik olması

- İnsanların birçok ürüne saniyeler içerisinde ulaşabilmesi

- Yararlanılan kampanya ve indirimlerin fazla olması

- Temassız ödeme imkânı

- Birçok ürün çeşitliğinin bulunması

- Özellikle evden çıkma ihtiyacı duyulmaması

Yukarıda sayılan nedenlerden dolayı salgınla birlikte e-ticaretin önemi gittikçe artmış, tüketiciler ve üreticiler geleneksel ticaretten e-ticarete doğru yönelmişlerdir.

\section{Sonuç}

E-ticaret kullanan işletmelerin, internet üzerinden günün her saatinde müşterilerine bilgi sunabileceği bir hizmeti oluşur. Elektronik ortamda bilgiler anında aktarıldığından zamandan tasarruf gerçekleşir. İşletme, müşterinin ihtiyacı olan ürünü internet ortamından müşteriye sunabilir. Günümüzde faaliyet gösterilen pazardaki rakiplerin bir adım önüne geçebilmek ve farklı pazarlarda faaliyet göstererek hedef pazarı büyütme fikri, işletmeleri e-ticaret kullanmaya teşvik etmektedir. Tüketiciler açısından ise, internet üzerinden alışveriş bilgiye hızlı ulaşma, ürünlerin uygun fiyatlı olanını yakalama, zaman tasarrufu ve satış elemanı baskısından uzak rahat bir alışveriş imkânı sunmaktadır. Özellikle seyahat ve tatil planlarının, elektronik aletlerin ve giyim ürünlerinin internet üzerinden satın alımı diğer ürünlere göre daha fazladır. Türkiye'de e-ticaret son 10 yılda artış eğilimi göstermektedir ve giderek artması beklenmektedir. E-ihracat açısından mesafelerin ticarete engel olmadığını gösterip, firmaları sınır ötesi müşterilerine ulaşıp, pazar paylarını arttırmaları açısından imkân sağlamaktadır. Küresel ticarette artan rekabet koşulları düşünüldüğünde Türkiye'deki firmaların özellikle hazır giyim firmalarının sınır ötesi ticarette yer almaları önem arz etmektedir. Yurt içi e-ticaret ve sınır ötesi eticaretin Türkiye'de yerleşmesi için birtakım engeller vardır. Tüketici güveni, dolandırılma düşünceleri, 
ödeme, kargo ve iadelerde çıkabilecek sorunlar, e-ihracatta ayrıca karşılaşılabilecek, yeterli yabancı dilde hizmet verebilecek internet siteleri, çağrı merkezleri gibi sorunlar ile gümrük işlemlerinin hızı genel engeller sayılabilmektedir. Bu bağlamda devletin e-ticareti ve e-ihracatı teşvik edici destekler sunması, gerekli düzenlemeleri yapması yurt içi ve yurt dışı ticaretin gelişmesi açısından önem teşkil etmektedir.

Covid-19 salgını da gösterdi ki, artık tüketiciler internet üzerinden alışverişe yönelmektedirler. Daha hızlı ve pratik olması, sosyal mesafenin sağlanması (kapıda teslim nedeniyle-daha az kişiyle temas) gibi nedenlerle e-ticaret salgın döneminde kurtarıcı bir yol olmuş ve önemi artmıştır.

Türkiye'de son yıllarda artış eğilimi gösteren e-ticaret ve e-ihracatla ilgili veriler sınırlı olduğundan, çalışma kapsamında ilgili kurumların raporlarından faydalanılmıştır. E-ihracatın ilerleyen yıllarda sağlanacak verilerle, e-ihracatın toplam ihracata ve milli gelire katkısı ilerideki araştırmalar için yapılabilir. 


\section{KAYNAKÇA}

Alan, E. (2017). E-ticaret türleri - elektronik ticaret iş modelleri. https://www.ihracat.co/2017/ 01/eticaret-turleri-elektronik-ticaret-is.html

Altıntaş vd. (2006). E-ticaret engellerinin e-ticaret kullanma eğilimine etkisi: Türkiye'deki ihracatçı KOBİ’ler üzerinde ampirik bir araştırma. Ankara Üniversitesi SBF Dergisi, 61(4), 37-58.

Cin, E. (2019). 2018'de online alışverişs ile tam 60 milyar lira harcadık! https://www.girisimhaber.com/post/2019/02/25/2018-Yilinda-Internette-60-Milyar-Lira-Harc adik.aspx

Demirbaş, E. (2014). An Integrative Model on the Factors Affecting Consumer's Satisfaction, Trust and Repurchase Intention in Online Shopping (385554) [Doktora tezi, Bahçeşehir Üniversitesi]. Yükseköğretim Kurulu Ulusal Tez Merkezi'nden edinilmiştir.

Demirdöğmez, M., Gültekin, N., \& Taş, H. Y. (2018). Türkiye'de e-ticaret sektörünün yıllara göre gelişimi. OPUS - Uluslararası Toplum Araştırmaları Dergisi, 8(15), 2216-2237. doi: 10.26466/opus. 453147

Elektronik Ticaret Rehberi (2006). Elektronik ticaretin etkileri ve faydaları. http://www.elektronik ticaretrehberi.com/e-ticaretin_etkileri_faydalari.php

Elektronik İmza Kanunu. (2004, 23 Ocak). Resmi Gazete (Sayı: 25355). https://www.resmigazete. gov.tr/eskiler/2004/01/20040123.htm

Ersoy, C. (2015). Elektronik ticaretin türleri. https://slideplayer.biz.tr/slide/3674454/

E-İhracat Stratejisi ve Eylem Planı (2018-2020). (2018, 06 Şubat) Resmi Gazete (Sayı: 30324). https://www.resmigazete.gov.tr/eskiler/2018/02/20180206-6.pdf

E-Ticaret Bilgi Bankası (2020). Corona virüsün ekonomiye etkisi ve e-ticaret'in yükselişi. https://www.ticimax.com/blog/corona-virusun-ekonomiye-etkisi-ve-e-ticaretin-yukselisi

E-Ticaret Bilgi Platformu (2020). E-Ticaret Istatistikleri. https://www.eticaret.gov.tr/istatistikler

E-Ticaret Günlüğü (2015). E-ihracata devlet destekleri. https://eticaretgunlugu.com/e-ihracata-devletdestekleri/

Güven, H. (2020). Covid-19 pandemik kriz sürecinde e-ticarette meydana gelen değişimler. ASEAD, 7(5), 251-268.

İhracatı Geliştirme Merkezi (2018). E-ticaret, e-ihracat, e-uluslararası ticaret, e-dış ticaretin; dış ticarete etkileri. https://www.igeme.com.tr/e-ticaret-e-ihracat-e-uluslararasi-ticaret-e-dis-ticaretin-disticarete-etkileri/

Kara, M. (2019). E-dlş ticaret ve ihracatta müşteri bulma yöntemleri. İstanbul Üniversitesi.

Kara, M., \& Coşkun, A. (2012). E-dış ticarette karşılaşılan sorunlar ve çözüm önerileri: Gıda sektörü örneği. Dumlupinar Üniversitesi Sosyal Bilimler Dergisi, 33, 183-192.

Kuşat, N. (2016). İşletmeden işletmeye (B2B) elektronik pazaryerleri ve gelişmekte olan ülkelerin diş ticaretinde uygulanabilirliği. Yönetim ve Ekonomi Celal Bayar Üniversitesi Íktisadi ve İdari Bilimler Fakültesi Dergisi, 23(3), 691-709. doi: 10.18657/yonveek.281808

Muradoğlu (2020). Covid-19'la birlikte Türkiye'de online harcama tutarında nasıl bir değişim yaşandı? https://webrazzi.com/2020/04/07/covid-19-la-birlikte-turkiye-de-online-harcama-tutarindanasil-bir-degisim-yasandi/

Mzwri, A.M.N., \& Altıkaya, Z. (2019). The impact of e-commerce on international trade: Case of Turkey. International Journal of Contemporary Research and Review, 10(01), 21190-21209. doi: 10.15520/ijcrr.v10i01.641

Organisation for Economic Co-operation and Development (2013). Glossary of statistical terms: Electronic commerce. https://stats.oecd.org/glossary/detail.asp?ID=4721 
Standart Uluslararası Ticaret Sinıflamasına (SITC, Rev. 3) Göre İhracat, 1996-2019 (2019b). Türkiye İstatistik Kurumu. http://www.tuik.gov.tr/PreTablo.do?alt_id=1046

T.C. Ticaret Bakanlığı İhracat Genel Müdürlüğü (2018). E-ihracat onayı verilen internet siteler. https://ticaret.gov.tr/data/5b8d9c6913b876125c08b4de/TicaretBakanligi_OnayVerilenETicare tSiteleriListesi2019.pdf

T.C. Ticaret Bakanlığı (2019). Dijital ticaret tanım ve kavramlar. https://www.ticaret.gov.tr/hizmetticareti/elektronik-ticaret/dijital-ticaret-tanim-ve-kavramlar

Terzi, N. (2011). The impact of e-commerce on international trade and employment. Procedia Social and Behavioral Sciences, 24, 745-753. doi:10.1016/j.sbspro.2011.09.010

Tu, Y. \& Shangguan, J.Z. (2018). Cross-border e-commerce: A new driver of global trade: emerging issues in global marketing. Springer International Publishing AG. doi: 10.1007/978-3-31974129-1_4

Türkiye Bilişim Sanayiciler Derneği (2019). Türkiye'de e-ticaret 2018 pazar büyüklüğü. TÜBİSAD, http://www.tubisad.org.tr/tr/images/pdf/tubisad_e-ticaret_2019_pazar_buyuklugu_raporu.pdf

Türkiye Ekonomi Politikaları Araştırma Vakfı (2014). Türkiye'de e-ihracat: firsatlar ve sorunlar. TEPAV Yayınları.

Türkiye İstatistik Kurumu (2019). Hanehalkı bilişim teknolojileri kullanım araştırması (2019). TÜíK. https://data.tuik.gov.tr/Bulten/Index?p=Hanehalki-Bilisim-Teknolojileri-(BT)-KullanimArastirmasi-2019-30574

Türkmen, B. (2016). E-ticaretin türleri nelerdir? https://isekonomi.com/e-ticaret-turleri-nelerdir-b2cb2b-c2cl

Uludağ İhracatçı Birlikleri -UİB (2017). E-dış ticaret raporu. UİB Yayınları.

Uluslararası Taşımacılık ve Lojistik Hizmet Üretenleri Derneği (2019). Türkiye'de e-ticaret ve eihracat: gelişim potansiyeli ve lojistik süreçler. UTIKKAD Yayınları.

Webrazzi (2018). E-ihracat rehberi. https://webrazzi.com/2018/11/14/turkiyenin-e-ihracat-gelecegi-vehedef-pazarin-belirlenmesindeki-anahtar-unsurlar/

World Trade Organisation (1998). Work Programme on Electronic Commerce, General Council Decision (98-3738).

World Trade Organisation (2019). Work Programme on Electronic Commerce, General Council Decision (19-8532).

World Trade Organisation (2020). E-Commerce, Trade and the Covid-19 Pandemic. https://www.wto.org/english/tratop_e/covid19_e/ecommerce_report_e.pdf

Xing, Z. (2017). The impacts of Information and Communications Technology (ICT) and e-commerce on bilateral trade flows. International Economics and Economic Policy, 15, 565-586. doi: 10.1007/s10368-017-0375-5

Yeşil, A. (2010). E-ticaret (2. Bask1). Kum Saati Yayınları. 